Derleme Makalesi - Review Article

\title{
HVDC Güç İletim Sistemleri Konusunda Bir Derleme
}

\author{
Mahir Kutay ${ }^{1}$, Ahmad Mustapha Usman ${ }^{2}$ \\ Geliş / Received: 25/02/2020 \\ Revize / Revised: 20/07/2020 \\ Kabul / Accepted: 21/07/2020 \\ $\overline{\mathbf{O Z Z}}$
}

Elektrik enerjisi, dünyaçapında "AlternatifAkım" (AC) olarak üretilir ve taşınır. Bununlabirlikte, "DoğruAkım" (DC) güç iletiminin $\mathrm{AC}$ 'den daha üstün olduğu bazı uygulamalar vardır. DC'den AC'ye ve AC'den DC'ye dönüşümler için iyi bir control ve düzenleme sağlayan teknoloji eksikliğinden kaynaklanan sorunlar nedeniyle, DC güç iletim teknolojisi yaygınlaşmamıştır. Güç elektroniği cihazlarının geliştirilmesi, "Yüksek Gerilim Doğru Akım" (HVDC) güç aktarımındaki kısıtlamaların büyük bir kısmını kaldırmıştır. HVDC kullanımı, ekonomik faydaları ve "Yüksek Gerilim Alternatif Akım" (HVAC) güç aktarımına gore teknik avantajları nedeniyle uzun bir süredir günlük kullanımın bir parçası olmuştur. HVDC uzun mesafelerde güç aktarımında kayıpların azaltılması ve farklı frekanslarda çalışan ülkelerin güç sistemlerini birbirine bağlamasında HVAC ye gore daha avantajlıdır. Bu makalede HVDC ilkeleri tanıtılmakta, HVDC'nin dünyadaki uygulamaları karşılaştırılmaktave bu teknolojide gelecekte ihtiyaç duyulacak gelişmeler tartışılmaktadır.

Anahtar Kelimeler- HVDC, Tristör, IGBT, Tekkutuplu HVDC

1*Sorumlu yazar iletișim: mahir.kutay@yasar.edu.tr (https://orcid.org/0000-0001-7572-4511)

Uygulamalı Bilimler Yüksek Okulu, Yaşar Üniversitesi, Bornova/İzmir

2İletişim: ahmadusmanmustapha@gmail.com (https://orcid.org/ 0000-0003-1753-516X)

Elektrik-Elektronik Mühendisliği Bölümü, Yaşar Üniversitesi, Bornova/İzmir 


\title{
A Survey on HVDC Power Transmission Systems
}

\begin{abstract}
Electric power is generated and transported globally by the means of an "Alternating Current" (AC) process. However, there are some applications in which "Direct Current" (DC) power transmission is superior to AC. Problems due to the lack of technology that provides good control and regulation for conversions of DC-to-AC and AC-to-DC hampered deployment of DC power transmission technology. The development of power electronic devices has removed a large portion of restrictions on "High Voltage Direct Current" (HVDC) power transportation. HVDC use has become part of daily use for a long time due to its economic benefits and technical advantages over the "High Voltage Alternating Current" (HVAC) power transmission. The advantages of HVDC make it suitable for power transmission over long distances and for connecting power systems of countries operating at different frequencies. This paper introduces the principles of HVDC, compares the applications of HVDC in the world, and discusses the future improvements needed within this technology.
\end{abstract}




\section{INTRODUCTION}

Electricity is generated and transmitted as AC all over the world. During the $19^{\text {th }}$ and the $20^{\text {th }}$ centuries, HVAC transmission was kept as the dominant power transmission technology. As the power generation and transmission capacity increased, several important problems for HVAC systems emerged. Increasing the transmission capacity and range of undersea cables, to transport a vast amount of hydropower from remote locations to load centers over very long distances were the major challenges. During the 1920 s, it was recognized that HVDC could be an efficient solution for both cases. Towards the end of the 1920s, mercury arc rectifiers were invented, but they could not be adapted to HVDC applications because of performance and capacity problems. The first application of mercury arc rectifiers to a commercial project became operational in 1954. This year, the first HVDC undersea power transmission line commissioned in Gotland (Sweden) [1]. In 1957, semiconductor thyristor developed as an alternative to mercury arc rectifiers. During the first half of the 1960s, thyristor technology evolved, and the high-voltage thyristor attracted the interest of the industry. In the spring of 1967, mercury-arc rectifiers used in the Gotland (Sweden) HVDC link was replaced by thyristors. It was the first time application of thyristors taken into commercial operation for HVDC transmission [2]. Nowadays HVDC lines used globally to transmit a large amount of power from the production site to the consumption areas over long distances [3]. The main reason is that HVDC is more effective than AC transmissions in all aspects of power system transmissions due to the fewer losses. Some applications of HVDC like undersea power transmission and facilitation of power transmissions between neighbor countries that use different AC frequencies are superior to HVAC.

\section{HVDC FUNDAMENTALS}

HVDC is a process by the use of high voltage generation and direct current, a huge amount of power picked up from one remote location to transport over the electrical power system. High voltage helps us in terms of a reduction process in the losses through transmission lines. Therefore, if the voltage stepped up at higher levels, it will have a smaller amount of current, and therefore a huge reduction in the electrical losses will be achieved [4]. This is the force behind the higher level of the voltage in HVDC. In countries, such as India and China, HVDC is the safest and the most economical way of transporting power over long distances. [5], [6].

\section{A. Main Components of the HVDC Systems}

The main components in the HVDC systems circuit listed as follows [7,8,9]:

- Converter Station: This is the main station where the use and functions of the rectifiers and inverters used for the AC-DC conversion process.

- Smoothing Reactors: The main functions of this reactor smoothing is that it exhibits the process of taking away or removing any existing AC components that were available or present in the HVDC systems.

- Filters: The importance of using the filter in this process is to remove any unwanted signal distortion in the process of using the AC and DC systems.

- DC interconnections.

- Circuit Breakers: They clear any abnormalities in the transformer and in the DC circuits.

\section{B. HVDC Limitations}

The factors to be considered in the field of HVDC are the switching, conversion, and control. The limitations are listed below:

- Reactive power is needed in a large amounts because the switching and the conversion generate an unwanted signal/disturbances in the systems, which in turn require the use of AC and DC filters.

- Converters are very costly.

- Change in the voltage level cannot be easily controlled by the use of transformers. 


\begin{tabular}{|c|c|c|}
\hline & $\begin{array}{l}\text { BŞEÜ Fen Bilimleri Dergisi } \\
7(2), 1170-1181,2020\end{array}$ & $\begin{array}{r}\text { BSEU Journal of Science } \\
\text { DOI: } 10.35193 / \text { bseufbd.693132 }\end{array}$ \\
\hline VERSI & & 88-7575 (http://dergipark.gov.tr/bseufbd) \\
\hline
\end{tabular}

- Multi-terminal operations are very difficult.

- The manufacturing process of the HVDC circuit breakers is very complex.

\section{HVDC APPLICATIONS}

HVDC can all be used into the following categories of class according to $[3,7,8]$ :

- Interlinking of the Power Grids:

Connections of AC grids carried out by the purpose of its stability and the energy flow. In the case of any challenge, the linking has to be carried out by the HVDC. For example, any connection that involves the use of two different frequencies and voltage, AC connection is not possible in this situation.

- Connecting DC Links in an AC Grid:

HVDC links can be used within an AC grid under some certain conditions, such as the load's demand and occurrences of an unwanted disturbance in the power system.

- Underwater Power Transmission:

The first implementation of HVDC is undersea power transportation. Today, many approaches of HVDC power transportation are used in the world. HVDC serves loads on islands with the use of marine transmission cables.

\section{HVDC NETWORK CONFIGURATIONS}

HVDC network configurations can be classified as follows:

- Mono-polar lines

- Bipolar lines

- Homo-polar lines

- Back to Backlines

\section{A. Mono-polar HVDC Lines}

Mono-polar configuration is the most common configuration. As its name implies, this type of HVDC lines are constructed with only one negative polarity. Since corona effect of negative polarity is less compared with positive polarity, mono-polar lines are operated at the negative polarity $[10,11]$. The ground is functioning as the returning way. Mono-polar HVDC network connection layout is given in Figure 1.

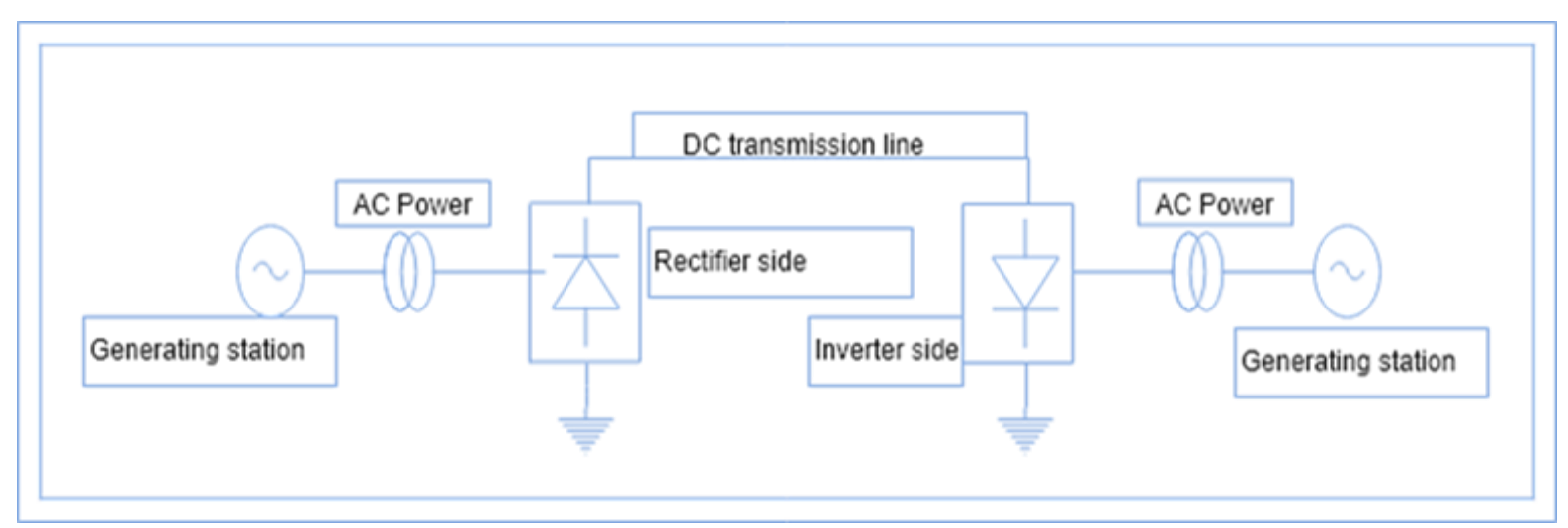

Figure 1. Mono-polar HVDC Lines 


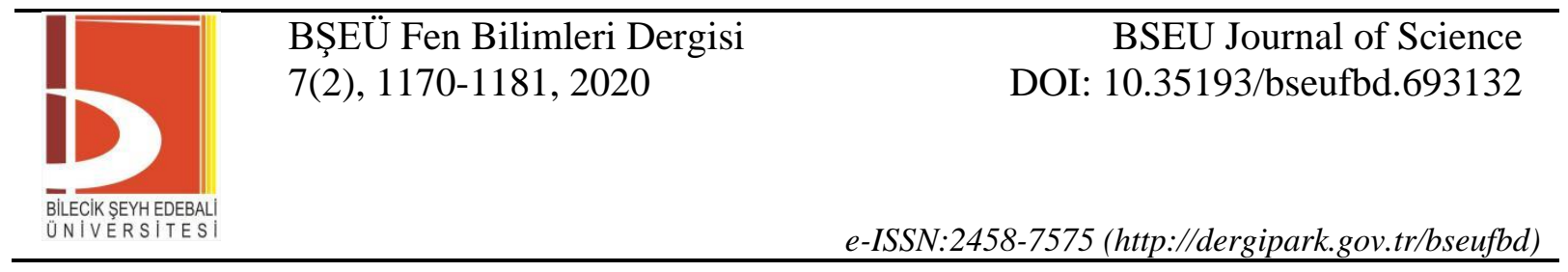

\section{B. Bipolar line Configuration}

The bipolar have two polarities of conductors which show the presence of both the positive and negative polarities in the systems. These two polarities of the conducting parts are arranged in the series of manner and operate at equal amount of voltage. As shown in Figure 2, the intersection of the converters grounded at one of the end or at both of the ends shown [12,13].

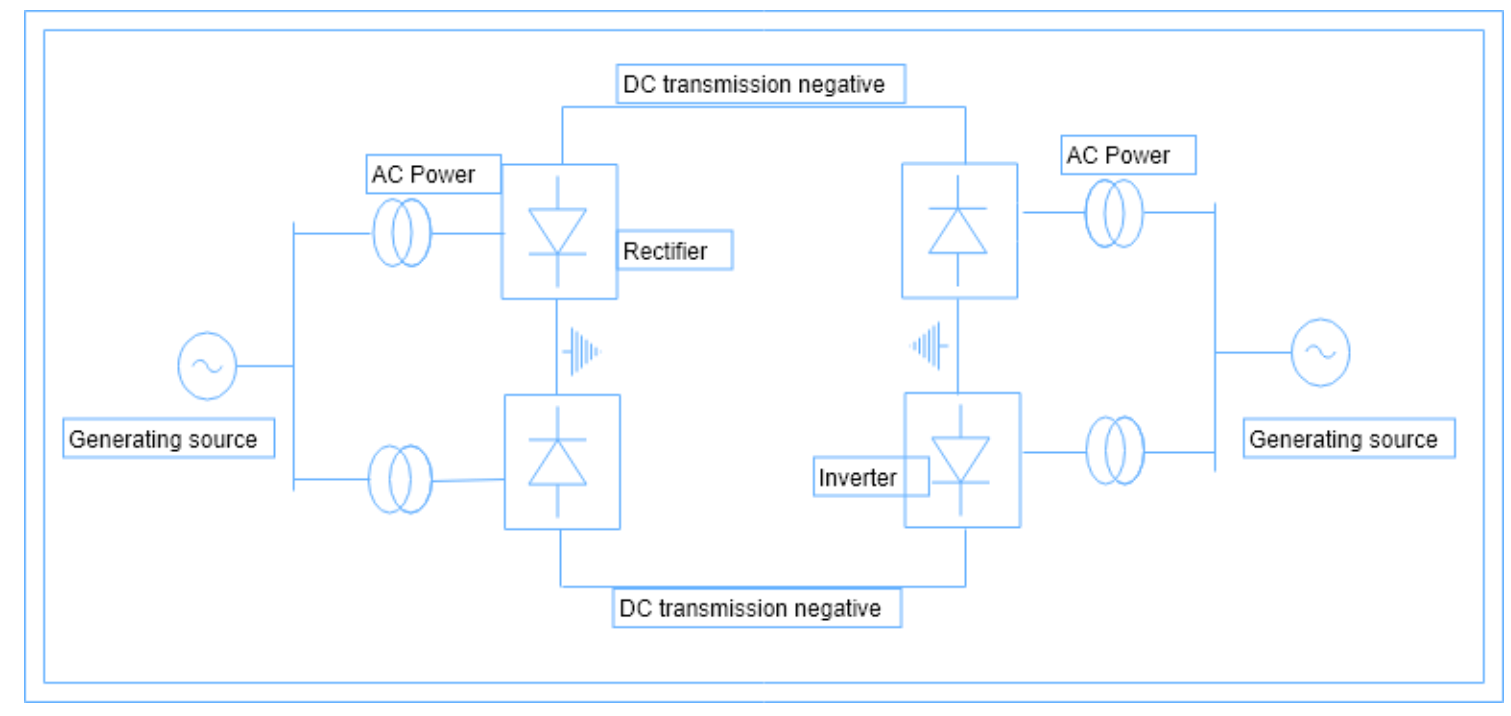

Figure 2. Bipolar HVDC System

\section{Homopolar HVDC System}

The homo-polar lines, as the name also goes by it means a type of HVDC system that contain more than two conductors having the same polarity, but they are in different form of the bipolar lines, and they always have earth as their path of return conductors, in which there mode of arrangement process is in the parallel manner as shown in Figure 3 [15].

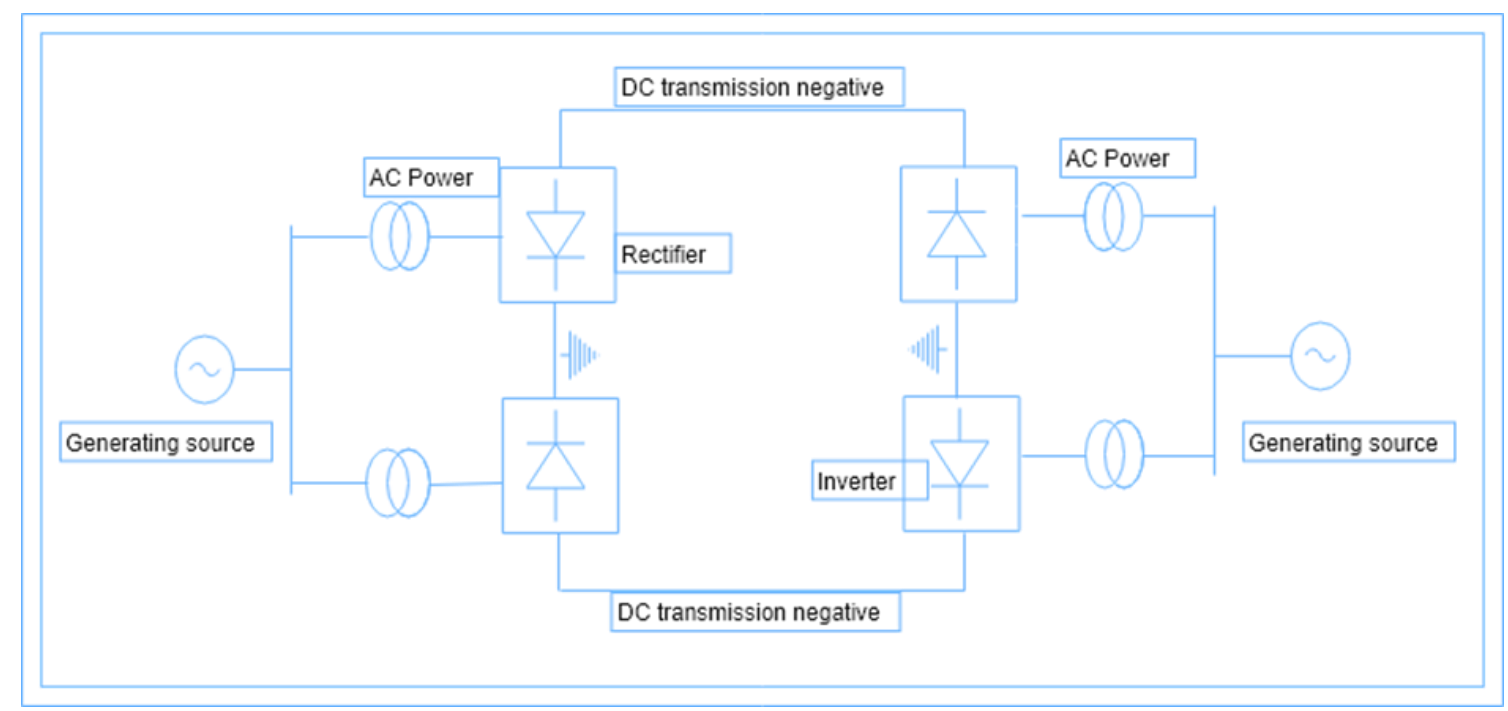

Figure 3. Homo-polar HVDC System 


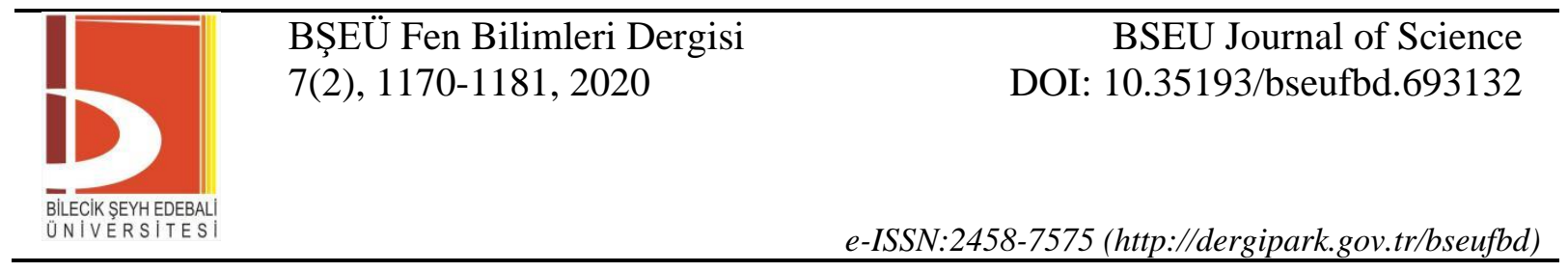

\section{Back-to-Back Lines}

A back-to-back HVDC connection is preferred when two different AC frequency systems are to be interconnected or for AC power system stabilization. HVDC back-to-back station does not contain overhead lines or cables for connecting the rectifier and the inverter. Therefore, DC transmission losses are negligible and DC voltage level is low, but the DC current amount is high.

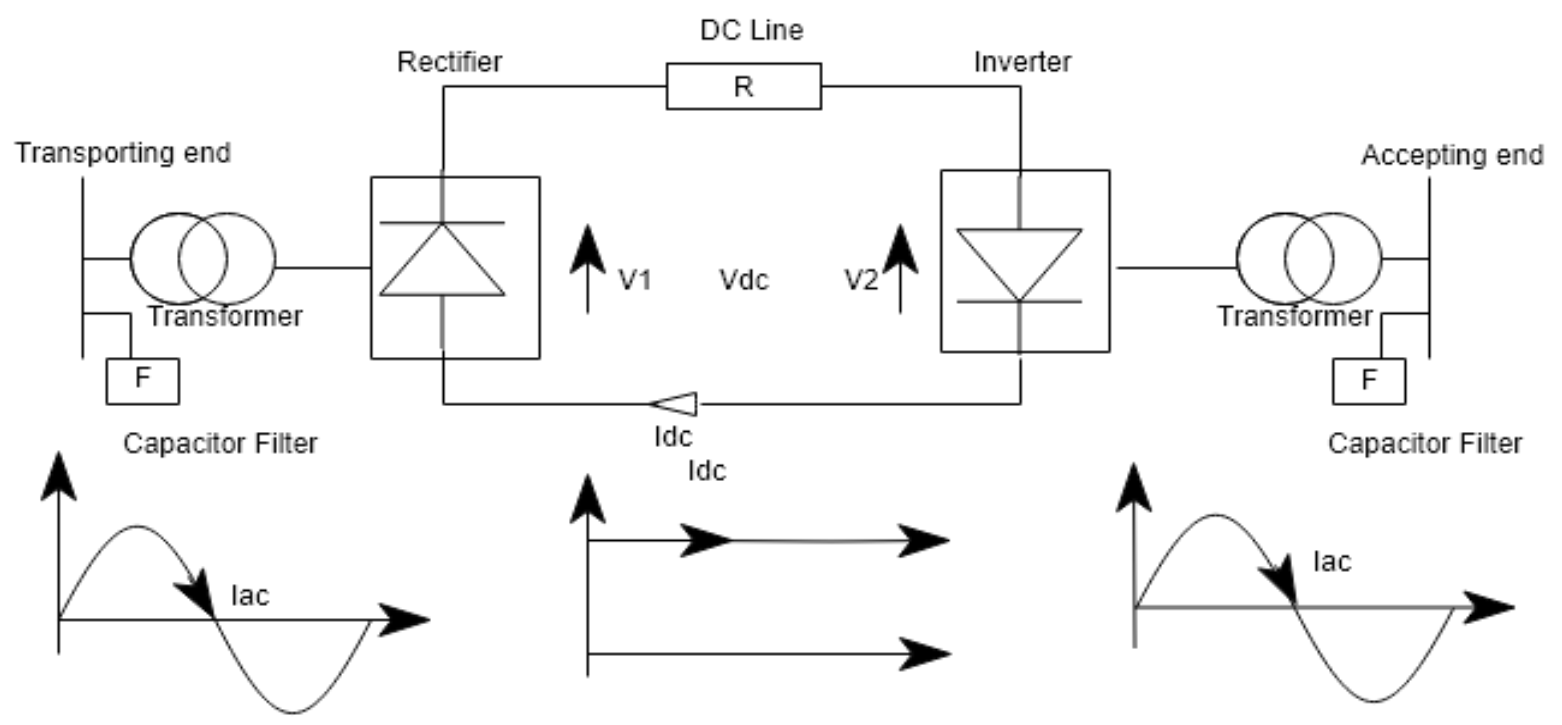

Figure 4. Back to back HVDC Lines

1) Multi-Terminal Direct Current Lines System (MTDC): This arrangement consists of three converters DC connection cables. Some of the converters function as a rectifier while the other functions as an inverter. This type of MTDC connection is shown in Figure 4. The AC power created by the use of power plant, such as the wind farm is transformed into DC by a rectifier and transported to two inverters by cables. Inverters again convert DC into AC feeding two transmission lines [16].

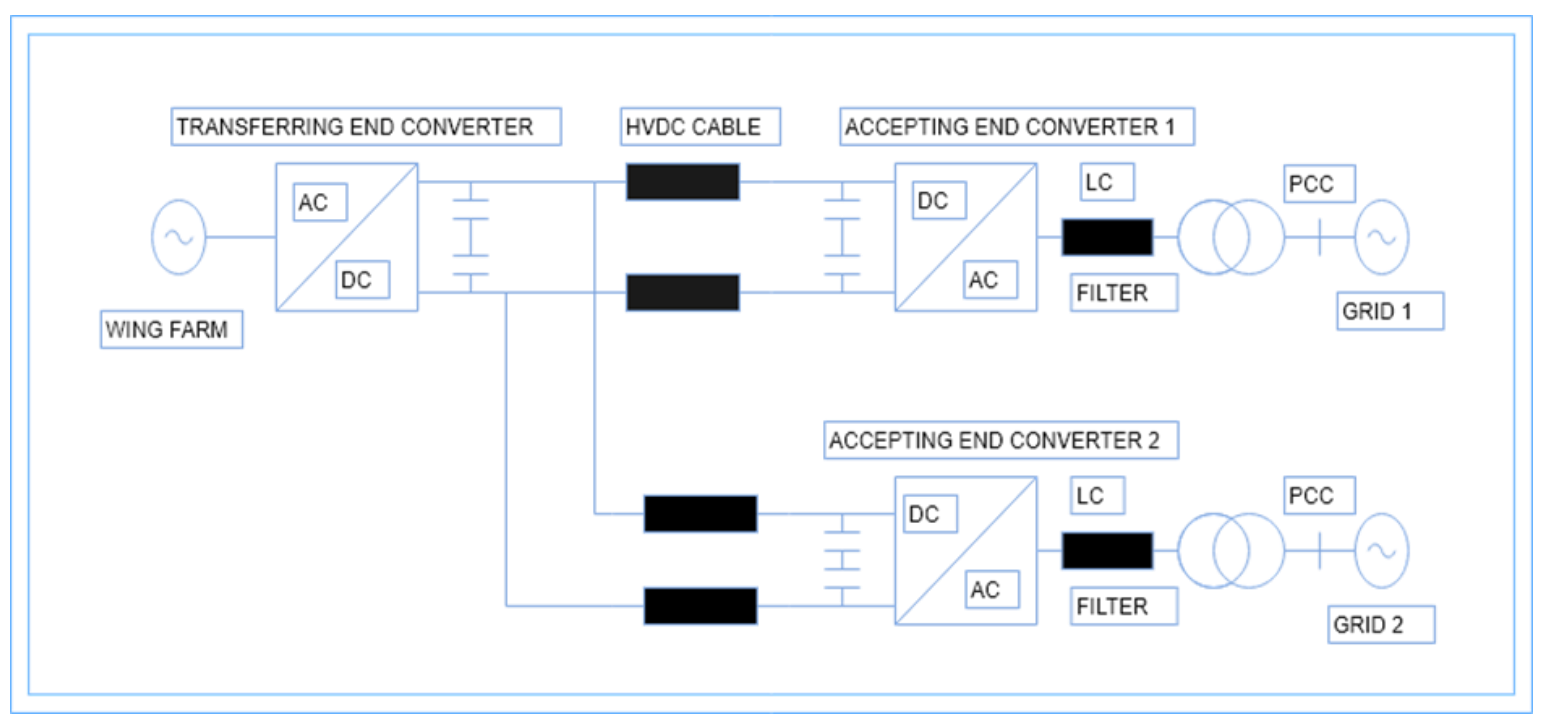

Figure 5.The MTDC Circuit Diagram 


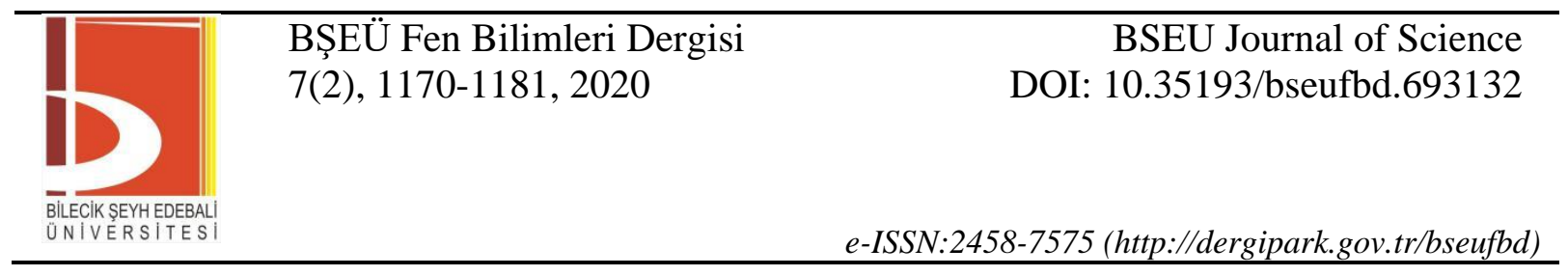

2) Types of MTDC Arrangements:

- Series MTDC lines system: In the series arrangement MTDC networks, the converters are arranged in a series of manner as shown in Figure 5.

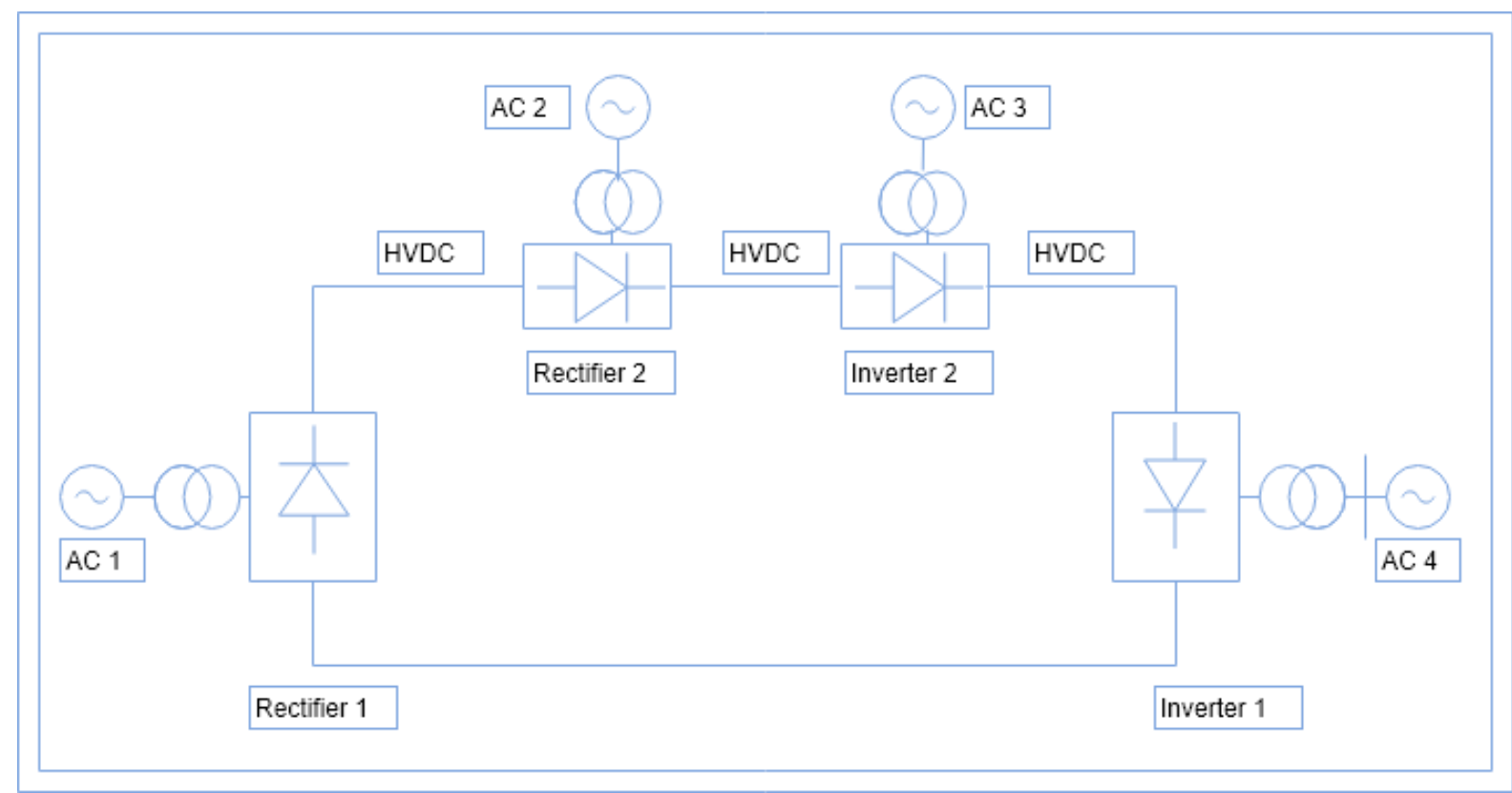

Figure 6.Series MTDC connections

- Parallel MTDC lines systems: The parallel arrangement for the MTDC networks, the converters connected in opposite to each other as shown in Figure 6.

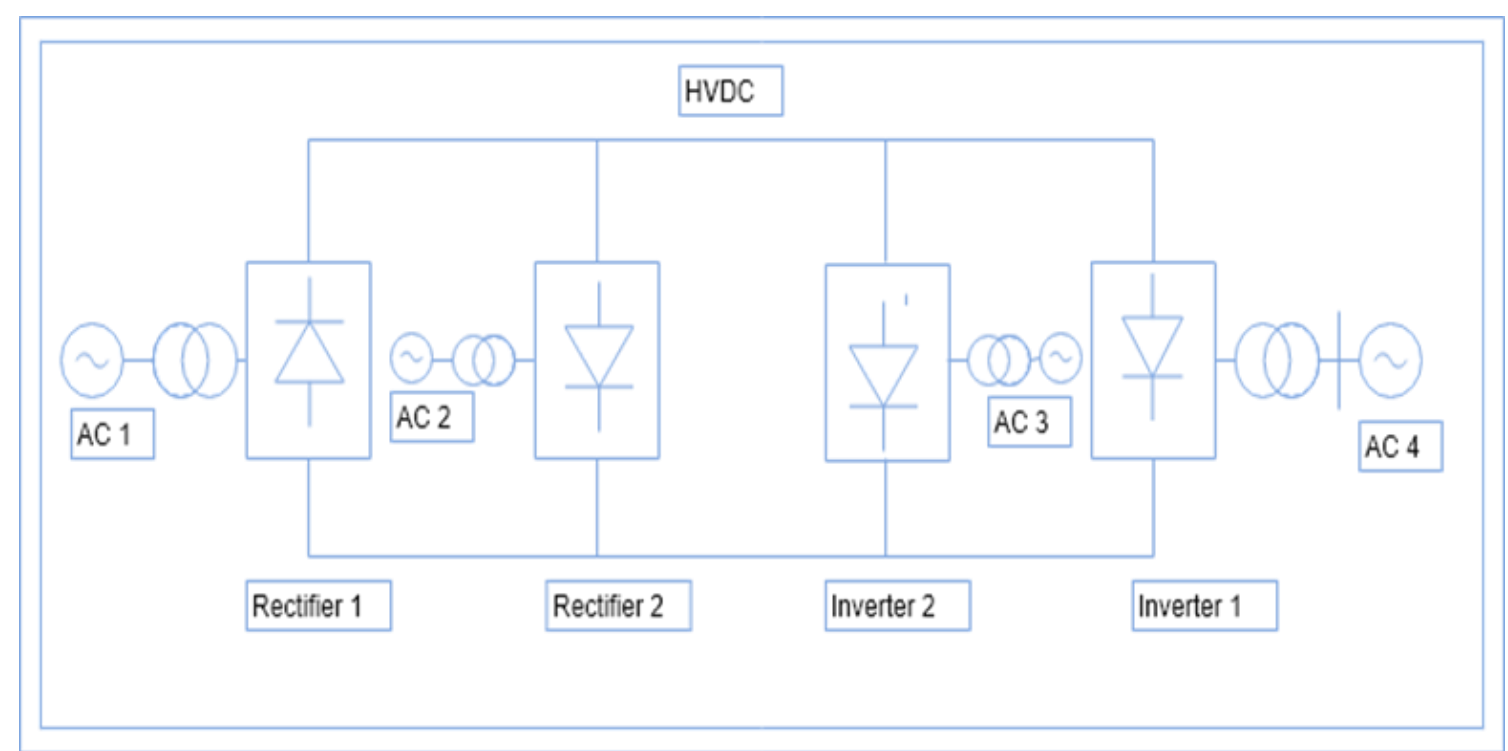

Figure 7. Parallel MTDC connections 


\begin{tabular}{|c|c|c|}
\hline & $\begin{array}{l}\text { BŞEÜ Fen Bilimleri Dergisi } \\
7(2), 1170-1181,2020\end{array}$ & $\begin{array}{r}\text { BSEU Journal of Science } \\
\text { DOI: } 10.35193 / \text { bseufbd.693132 }\end{array}$ \\
\hline $\begin{array}{l}\text { CIK SEYY EDEE } \\
\text { IVERSIT }\end{array}$ & & 58-7575 (http://dergipark.gov.tr/bseufbd) \\
\hline
\end{tabular}

\section{COMPARISON of HVDC and HVAC in TERMS of COST}

$\mathrm{AC}$ is widely used for a short range of distances mostly for domestic purposes, such as the residential, commercial, and industrial purposes. The AC transmission in short range costs less voltage and frequency controlled easily. The use of $\mathrm{AC}$ for a huge project is problematic. Voltage and frequency control tends to be very difficult and additionally, it has limitations. DC does not have any limitations attached to it and requires less investment cost. DC transmissions do not require too much use of conductor, unlike the AC systems. The use of both AC and DC transmission have been in use recently due to how we can both use them in transporting an electrical power from one far away location to the other by the means of converters, such as the rectifier and inverter [17-20]. Figure 7 shows the investment cost of both AC and DC transmission.

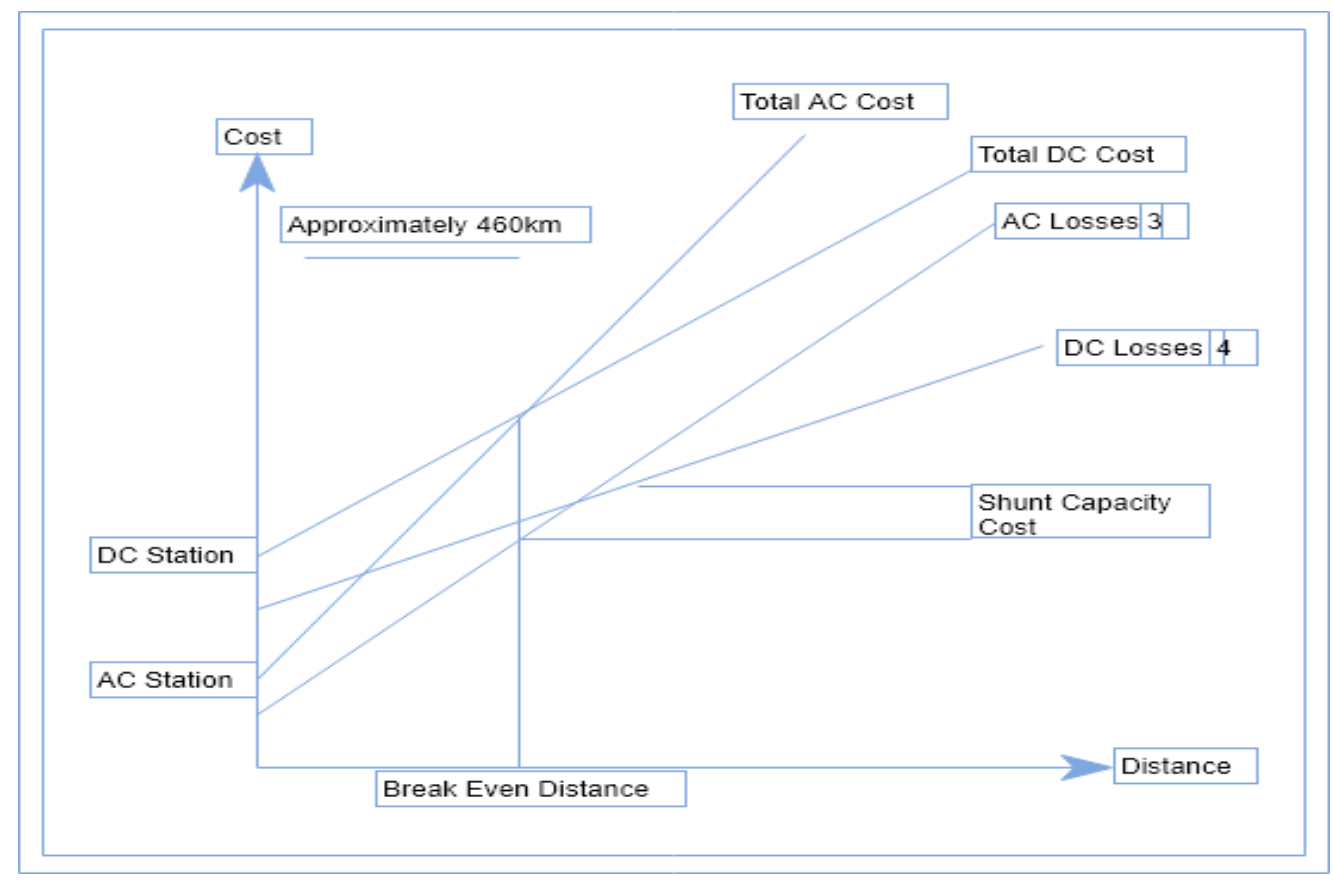

Figure 8. Investment cost comparison for AC and DC transmissions.

From the above graph, it can be concluded that there will be difficulties in realizing the cost reduction in the usage of transformers that have been working hand in hand with any $\mathrm{AC}$ transmissions process due to the a lot of progression that has been put forward into the creation of new devices that may be able to function between the converters.

\section{A. Commercial Development of HVDC in the World}

In the year 1954 the first commercial business of the HVDC started in Gotland [21]. Created in the Baltic water ocean between the two countries of Swedish terrain and Gotland island, the undertaking comprised in the exchange of intensity produced from Gotland island twist stop to the principle arrive [21]. This task was a big step to improve the idea of DC transmission technology. The outcomes were the presentation of thyristors in the 1960s.

As it can be seen from Tab.1.1, there are a few HVDC thyristor-based transmission systems all around the globe. They developed for the long transmission from the generation control point, for the most part, hydropower plant, to load centers.

In mainland Europe, the principal venture of association among England and France began in 1961 with the link generation of Lydd atomic power station in Great Britain to the French station at Schengen inverter station [22]. Worked at volt-generation of $100 \mathrm{kV}$ and $800 \mathrm{An}$, it was a bipolar cable 64km long. It was later in 1981, 
supplanted by two new $72 \mathrm{Km}$ bipolar submarine cables working at $270 \mathrm{KV}$ with influence exchange ability of 2000 Megawatts [23].

The Italian HVDC transmission connecting Sardinia, Corsica to Italy went in the task in 1965.Consisting of submarines cables of $103 \mathrm{~km}$ connecting Italy to Corsica and $15 \mathrm{~km}$ connecting Sardinia to Corsica, the system is a multipoint system that encourages generating energy trade among the numerous few static invertors dispersed between Italy, Corsica, and Sardinia. It has likewise three overhead lines, one on every locale: Italy territory, Corsica, and Sardinia with a length of $50 \mathrm{~km}, 167 \mathrm{~km}$ and $87 \mathrm{~km}$ individually. This establishment working at $200 \mathrm{kV}$ has control exchange ability of $200 \mathrm{MW}$ [24].

In Japan 1960, numerous HVDC transmission systems worked to interconnect distinctive archipelagos. In 1965, Japan eastern and western systems were interconnected through Sakuma HVDC convertor station.The station has control limit of $300 \mathrm{MW}$. After five years in 1970, two new convertors were placed in administration, with $37.5 \mathrm{MW}, 125 \mathrm{kV}$, at Sakuma testing station. The introduced converters were thyristor-based [25].

Table 1. HVDC Projects in the world.

\begin{tabular}{lccc}
\hline \multicolumn{1}{c}{ Project } & $\begin{array}{c}\text { Power } \\
\text { MW }\end{array}$ & $\begin{array}{c}\text { Distance } \\
\text { KM }\end{array}$ & $\begin{array}{c}\text { Voltage } \\
+/ \text { KV }\end{array}$ \\
\hline Azura-Edo Nigeria & 1930 & 1920 & 550 \\
Inga- Shaba, Congo & 560 & 1700 & 500 \\
Nelson River Canada & 4000 & 940 & 500 \\
Itaipu Brazil & 6300 & 790 & 600 \\
Quebec- New England & 2000 & 1480 & 450 \\
Pacific Intertie USA & 3000 & 1360 & 500 \\
Geszuba- Shanghai & 1200 & 1000 & 500 \\
New Zealand & 560 & 600 & 350 \\
Skgenerationrrak Denmark & 440 & 240 & $250 / 350$ \\
TSQ China & 2000 & 800 & 500 \\
Three Gorges- Guandong & 3000 & 940 & 500 \\
\hline
\end{tabular}

Table 1. HVDC Project in the world.

\section{POWER ELECTRONIC COMPONENTS USED FOR HVDC}

Early use of "mercury arc valves" are now being substituted with the recent inventions of the new creation of thyristors based that are now the most common use in any HVDC projects in the world. During the usage of the "mercury arc valves" observed problems listed below:

- The higher cost is observed.

- Absence and lack of control.

- The higher cost of regular checking/maintenance.

- The use of very large land required.

Thyristor replaced the usage of mercury-arc converters because of the following reasons:

- There is a minimal loss of power.

- Shorter recovery to time.

- Higher reliability.

- Very small switching losses

- Longer life span. 
- There is a greater presence of flexibility in the manufacturing process

The thyristor is operational when pulse is applied to the gate. Thyristor has three methods of working: Forward conducting mode, converse blocking mode, and forward blocking. It is in onward conducting stage until forward current results to becoming smaller to the threshold holding current. A thyristor circuit is not fully controllable [26-30].

Today's VSC (Voltage Source Converter) for HVDC replace thyristors by IGBTs (Insulated Gate Bipolar Transistor). IGBTs are fully controllable, which means conduction stage stopped by gate control. The IGBT-based VSCs creates fewer input harmonics and also operates at a very large power factors. Therefore, the need for supplementary apparatus, such as input harmonic filterates and SVCs (Static Var Compensators) eliminated [31]. The symbol for IGBT given in Figure 8.

\section{CORONA DISCHARGE ON HVDC TRANSMISSION LINES}

Corona is defined as a process whereby there is an emission in electrical that have been gotten by the process of ionization of an unstable fluid, such as the examples of Air being surrounded by an electrically charged conductor. Corona is one of the major setbacks that cause the loss of power on an HVDC transmission line as it makes it be less in terms of its economic value and also makes it unwanted. The emission or the process of giving out the corona are formed on the outer part of conducting materials due to the larger gatherings of an avalanche electrons [27-31]. Factors affecting the corona discharge summarized as follows:

- Distance between conductors

- Voltage level used in the transmission process.

- Atmospheric conditions.

- Conductor internal structure and size.

Problems created by corona discharge are given below:

- UV radiations

- Rays of light

- Sound when it is unbalanced in nature

- Acids and other technical factors

\section{FUTURE DEVELOPMENT}

The future development of the HVDC transportation process is of utmost concern and importance for the transmition of an electrical power to which it lies into integration of its several composites/complex interlinking networks. The idea behind this transportation of the power is due to the considerable amount of lower cost/budget that is involved in the approach and also the benefits of it in order to detour a very large amount of AC networks use [32]. Many countries in the world will now tend to be in connection of sharing power to the near countries which will tend to need the invention of a new approach like the use "large power plants system" which has to be linked to the HVDC process in order to have a more reliable and efficient power system transportation as can be observed from countries like Brazil, China, and other countries [33]. Studies have also shown that in countries like Pakistan, the entire electrical power transportation network is of about 40 electrical grid, consisting of an entire length of an HVAC lines nearly $12000 \mathrm{~km}$ in order to meet the requirement and satisfaction of its population needs. To have access to sufficient electrical power, it needs to create an electrical power of about 3-4MW per year and also with the help of applying the large power plant systems to its transmission processes.

\section{CONCLUSIONS}

- The use of HVDC systems was very reliable due to the minimal losses that were associated with the mode and process of using because of the lower amount of currents presence in the process. 
- It is very effective and dependable due to how it is being used in the process of moving clean energy sources from different places.

- There is also an unbalanced stability in the inverter systems. conversions.

- The most complex and difficult problems that were faced were the difficulties in the equipment

- Daily usage of HVDC systems is increasing day by day in the world.

\section{REFERENCES}

[1] AnoopDhayani A. P. et al., (2015) Design and Performance Analysis of HVDC Transmission System Under Different Fault Conditions. International Journal of Electrical and Electronics Engineering \& Telecommunications. ISSN 2319 - 2518.Vol. 1, No. 2, July 2015.

[2] Hossain Z., Hossain K., Hossain A., and Islam M., , "Performance analysis of a HVDC transmission system under steady state and faulted conditions”, Telkomnika Indonesian journal of electrical engineering, 12(8), pp. 5854-5860, 2014.

[3] Benish K. Paily. Ph.D. (2015) HVDC Systems Fault Analysis Using Various Signal Processing Techniques. Dublin Institute of Technology Republic of Ireland.

[4] Grant J., "Review of HVDC technology application and future prospects'. Research Gate,November, 2017.

[5] Edison S., Pugazhendi S., and Raj M. K., ' 'Review of fundamentals of HVDC transmissions', August 2014.

[6] Kim C. K., Sood V. K., Jang G. S., Lim S., and Lee S. J., HVDC Transmission power conversion applications in power systems, Wiley-IEEE Press, 2010.

[7] Padiyar K.R., HVDC Power Transmission Systems, 2nd Edition, New Academic Science, 2011.

[8] Eltamaly A. M., Sayed Y., and Elghaffar A. N., “ HVDC system operation and fault analysis”, IJET November, 2017.

[9] Grid Tech Team, Applications for HVDC technologies, U.S department of energy, April, 2013.

[10] Yu J., Karady G. G., “Applications of embedded HVDC in power system transmission”, IEEE Power engineering and automation conference, PEAM, 2013.

[11] Chandra S., Singh P., Gupta K., "Analysis of HVDC power transmission line with unique power control room”, IJSR,ISSN:2319-7064, 2015.

[12] Kamalapur G. D., ' HVDC transmission in india’’ IEEE 2014.

[13] Zeng P., Zhou Q., Dai Q.,"Study on the development and reliability of HVDC transmissions systems in China', IEEE International conference on power systems, 2016.

[14] Lidong Z, Lars D, “A novel method of mitigate commutation failures in HVDC Systems”, Proceedings of international conference on power system technology, 2002.

[15] Horiuchi, T. \& Kato, Y., “Japana prepares HVDC techniques to meet domestic need”, Energy international., 11(1), pp. 13-14, 1974.

[16] Adamson, C. and Hingorani, N. G., HVDC power transmission, Garaway Ltd, 1960. 
[17] Meah K., Ula S., "Comparative evaluation of HVDC and HVAC transmission systems", IEEE Power Engineering Society General Meeting, 2007.

[18] Daware K., "HVDC vs HVAC transmissions", retrieved December 17, 2018. From https://www.electricaleasy.com/2016/02/hvdc-vs-hvac.html.

[19] Long W. F., Editor "Comparison of costs and benefits for DC and AC transmission", OAK Ridge national laboratory, ORNL-6204, Feb 1987.

[20] Comparative evaluation of HVDC and HVAC transmission system, Conference paper, july 2007.

[21] Axelson A., Knosh G., The Gotland HVDC light Project, 2001.

[22] Goodrich, F. \& Andersen, B., "The 2000 MW HVDC link between England and France", Power engineering journal, March, 1(2), pp. 69-74., 1987.

[23] Mazzoldi, F., Taisne, J., Martin, C. \& Rowe, B., 1989. Adapation of the control equipment to permit 3terminal operation of HVDC link between Sardinia,Corsica and mainland Italy. IEEE,Power Delivery, April, 4(2), pp. 1269-1274.

[24] Franck C.M., ' HVDC circuit breaker:A review identifying the future research need for power delivery", IEEE transactions on power delivery, 26(2), 2011.

[25] Wadha, C.L, Electrical power systems sixth edition, New Age International Publishers, New Delhi, 2010.

[26] Motto W. J., 'Introduction to solid state power electronics", February 1977

[27] Arruda C, Lima A. C. S., " Corona modeling in HVDC transmission lines based on a modified particle-incell approach", Electric power systems research No:125, 2015.

[28] Ogar V. N., L., Bendor S. A., James A. E., " Analysis of a corona effects on hvdc transmission lines", American journal of engineering research (AJER), 6(7), pp. 75-87, 2017

[29] Retrieved December 222018 from:https://circuitglobe.com/corona-effect.html

[30] khani K.A., Applications of High voltage DC transmissions, Retrieved December 22, 2018 from:https://circuitglobe.com/corona-effect.html.

[31] William John motto, Jr: "HVDC Corona Space Charge Modeling and Measurement", IEEE Transactions on power delivery, 26(4), pp. 2630-2637, 2011.

[32] Breuer W, et al.: “Trends for future HVDC Applications”, Electric power supply industry, 2006.

[33] Future of HVDC power grid in Europe, retrieved March 11, 2019. From https://ocw.tudelft.nl/wpcontent/uploads/TGD-R3-HVDC-Power-Grid-Straka.pdf.

[34] Selvaraj E. et al., (2014) A Review on Fundamentals of HVDC Transmissions. Chennai, India 